\title{
25. K-Ar AGES OF DEEP-SEA BASALTS, BENHAM RISE, WEST PHILIPPINE BASIN, LEG 31, DEEP SEA DRILLING PROJECT
}

\author{
Edwin H. McKee, U.S. Geological Survey, Menlo Park, California
}

\section{INTRODUCTION}

Two samples of basalt separated stratigraphically from each other approximately 19 meters and from near the bottom of the nearly 445 -meter deep hole at DSDP Leg 31 Site 292, were dated by the K-Ar method. The dates, which are concordant, provide radiometric age control on the fossiliferous stratigraphic column above the basaltic basement and indicate that sedimentation above the calcium-carbonate compensation depth (CCD) started immediately after extrusion of the basalt.

\section{GEOLOGIC CONTROL}

Site 292 on the Benham Rise penetrated 365.5 meters of Quaternary through early Oligocene or late Eocene ooze, chalk, and minor chert. The biostratigraphic section is continuous and contains a variety of diagnostic fossil forms that were deposited above the CCD. Basalt was found at 367.5 meters and continued for the next 70 meters at which point drilling was stopped. The basalts recovered are very uniform intersertal to subophitic tholeiitic types. The two dated samples are from the bottom part of the hole, one from the lowest core recovered and the other 19 meters higher.

\section{SAMPLES}

Samples 31-292-45-2, 85-87 cm and 31-292-47-2, 67-69 $\mathrm{cm}$ were selected for dating by the K-Ar method because they contained the least intersertal glass (less than 5\%) and were the freshest of the samples that were examined in thin section. Both are intergranular to subophitic, medium- to fine-grained rocks, and therefore $\mathrm{Ar}^{40}$ produced by radiogenic decay of $\mathrm{K}^{40}$ should be retained at lattice sites of $\mathrm{K}$-bearing minerals. Loss of $\mathrm{Ar}^{40}$ by diffusion from devitrifying glass should be minimal in these rocks. They were also separated far enough from each other $(19 \mathrm{~m})$ so that local conditions that might cause argon loss or gain should not have affected both samples.

The ages of the two separate samples serve as a check on each other, and because they are the same within their analytical uncertainty, this age is considered to be the age of the basalt sequence.

\section{Analytical Procedure}

Both specimens were analyzed in the laboratories of the U.S. Geological Survey in Menlo Park, California, using identical procedures described by Dalrymple and Lanphere (1969). Cubes weighing about $5 \mathrm{~g}$ were cut from the center of the sample previously examined in thin section. Two parts of the cube, each weighing about $1 \mathrm{~g}$, were powdered and analyzed for $\mathrm{K}_{2} \mathrm{O}$; the remainder, about $3 \mathrm{~g}$, was fused in the argon extraction.
The argon mass analyses were carried out using standard isotope-dilution techniques with a Nier-type 6-in.radius $60^{\circ}$-sector mass spectrometer operated in the static mode.The potassium analyses were done in duplicate for each sample by flame photometer using a lithium internal standard. The decay constants used for $\mathrm{K}^{40}$ are $\lambda \mathrm{e}=0.585 \times 10^{-10} \mathrm{yr}^{-1}$ and $\lambda \beta=472 \times 10^{-10}$ $\mathrm{yr}^{-1}$, and an atomic abundance of $\mathrm{K}^{40}$ of $1.19 \times 10^{-4}$ mole/mole.

The \pm value attached to the age is the estimated analytical uncertainty at 1 standard deviation and represents uncertainty in the measurement of radiogenic $\mathrm{Ar}^{40}$ and potassium in the sample. The value is determined on the basis of experience with replicate analyses in the Menlo Park laboratories. The estimated error for the two samples, both with more than $60 \%$ radiogenic $\mathrm{Ar}^{40}$, is about $3 \%$ of the age.

\section{AGES}

Sample $292-45-2,85-87 \mathrm{~cm}$, the stratigraphically higher of the two, yielded an apparent age of $38.2 \pm 1 \mathrm{~m} . \mathrm{y}$. (Table 1). Sample 292-47-2, 67-69 cm, 19 meters below the first sample, yielded an apparent age of $37.1 \pm 1$ m.y. (Table 1).

Because the two samples contain a large proportion of radiogenic $\mathrm{Ar}^{40}$ (64.5\% and $70.4 \%$ ), uncertainty in the age calculation is relatively low. This factor and the concordance of the ages suggest that these basalts are about 37 to $38 \mathrm{~m}$.y. old. It is highly unlikely that identical partial loss or gain of argon to give fortuitously similar ages from two rocks containing a variety of sites of argonproducing $\mathrm{K}^{40}$ would happen.

\section{FOSSIL AGE AND RADIOMETRIC AGE}

A nearly continuous succession of calcareous nannofossils and foraminifera ranging from Quaternary through Miocene and calcareous nannofossils, foraminifera, and radiolarians in the Oligocene or late Eocene was identified in the cores from Site 292. The boundary between the Oligocene and Eocene is recognized in Core 35 on the basis of foraminifera and radiolarians, and in Core 36 on the basis of nannofossils. This discrepancy in stratigraphic position of the boundary appears to reflect a matter of boundary definition since all three fossil groups occur in equivalent time zones (Bukry, 1973). The highest basalt occurs about 40 meters below the Eocene-Oligocene boundary, and the intervening sediments contain forms that are classified as late Eocene or early Oligocene in age. On the basis of the fauna in the overlying sediments, the basalt can be considered to be early Oligocene or late Eocene or older. In terms of an absolute age, the fauna indicate that the basalts are the same or are somewhat older than 37.5 
TABLE 1

K-Ar Dating, Leg 31, Site 292 Samples

\begin{tabular}{cccccc}
\hline Core & $\begin{array}{c}\text { Material } \\
\text { Dated }\end{array}$ & $\begin{array}{c}\mathrm{K}_{2} \mathrm{O} \\
(\%)\end{array}$ & $\begin{array}{c}\mathrm{Ar}^{40} \mathrm{Rad} \\
(\mathrm{mole} / \mathrm{g})\end{array}$ & $\frac{\mathrm{Ar}^{40} \mathrm{Rad}}{\mathrm{Ar}^{40} \text { Total }} \times 100$ & $\begin{array}{c}\text { Apparent Age } \\
(\mathrm{m} . \mathrm{y} .)\end{array}$ \\
\hline 45 & Whole rock & $\begin{array}{c}0.573 \\
47\end{array}$ & $3.225 \times 10^{-11}$ & 70.4 & $38.2 \pm 1$ \\
& Whole rock & 0.558 & & & $37.1 \pm 1$ \\
& & 0.565 & $3.100 \times 10^{-11}$ & 64.5 & \\
\hline
\end{tabular}

m.y.- the Eocene-Oligocene boundary on the Berggren (1972, fig. 1) time scale.

The two basalts with concordant $\mathrm{K}$-Ar ages of 37.1 \pm 1 and $38.2 \pm 1 \mathrm{~m} . \mathrm{y}$. allow an age somewhere between 36.1 and 39.2 m.y., using the limits of analytical uncertainty. This coincides well with the age indicated by the fauna and indicates that sediments started to accumulate soon after the extrusion of the basalt.

\section{TECTONIC IMPLICATIONS}

Shallow-water fossils including ostracodes, echinoid spines, and the nannofossil Braarudosphaera were found in the lower part of the sedimentary sequence (Cores 31, $33,34,36$, and 39) - the late Eocene or early Oligocene part of the core. Higher parts of the core contain deeper water forms, but preservation of calcareous types indicates that deposition was above the CCD. The fossil record suggests that water depth increased through time from an initially relatively shallow period in the late Eocene or early Oligocene. The basaltic basement, between 36.1 and $39.2 \mathrm{~m} . \mathrm{y}$. old (late Eocene or early Oligocene), is about the same age as the oldest sediments. This basement must have formed at shallow depth and is not part of an old deep basin basement that was uplifted and received its sedimentary cover.

\section{REFERENCES}

Berggren, W. A., 1972. A Cenozoic time-scale-some implications for regional geology and paleobiogeography. Lethaia, v. 5, p. 195-215.

Bukry, D., 1973. Coccolith stratigraphy, eastern equatorial Pacific, Leg 16 Deep Sea Drilling Project. In van Andel, T. H., Heath, G. R., et al., Initial Reports of the Deep Sea Drilling Project, Volume 16: Washington (U.S. Government Printing Office), p. 653-711.

Dalrymple, G. B. and Lanphere, M. A., 1969. Potassiumargon dating: San Francisco (W. H. Freeman). 